\title{
WHAT'S \\ HAPPENING \\ IN \\ Without Borders
}

\section{From the Editor}

\section{Gretchen Birbeck, MD, MPH}

\section{About without borders}

Without Borders is a valuable resource for those interested in global neurology. The site features current editor and guest blogs, links to pertinent resources, author interviews, current research, and much more.

\section{Recent updates}

The Without Borders Extra Extra section not only promotes educational opportunities and global neurology-related conference events, but also aids researchers in gathering data. Researchers can connect with global neurology specialists, fellows, or residents and ask for their assistance completing surveys on various topics of interest to the global neurology community.

Recently, Without Borders was contacted regarding a survey being done at John Hopkins. The researchers made this request:

"We are conducting a research study of the impact of global health experiences during neurology training on an individual's clinical skills and knowledge, career development, and long-term practice. If you completed a global health experience (i.e., clinical, research, and/or educational) within the last 10 years that took place during your neurology residency or fellowship, we would sincerely appreciate your participation. In addition, if you know neurologists who participated in global health experiences during their neurology training, we would appreciate if you would also forward this [request] email to them."

The link to this anonymous online survey via RedCap can currently be found in the Without Borders Extra Extra section. The survey takes about 10-15 minutes to complete, and completion of the survey means you are consenting to participate in this research study. This survey will remain open through February 2020.

\section{Blog}

Read the Without Borders blog for timely posts by the editor and invited guests. NPub.org/wbblog 


\title{
Neurology
}

\author{
What's happening in Without Borders \\ Neurology 2020;94;164 \\ DOI 10.1212/WNL.0000000000008836
}

This information is current as of January 27, 2020

\section{Updated Information \&} Services

Permissions \& Licensing

\section{Reprints}

including high resolution figures, can be found at: http://n.neurology.org/content/94/4/164.full

Information about reproducing this article in parts (figures,tables) or in its entirety can be found online at:

http://www.neurology.org/about/about_the_journal\#permissions

Information about ordering reprints can be found online:

http://n.neurology.org/subscribers/advertise

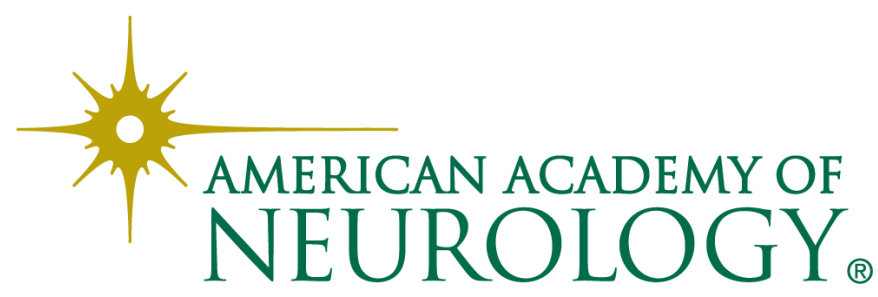

